\title{
The AACVD of CFTS Family of Materials
}

\author{
Yousef Alghamdi \\ Department of Chemistry, Faculty of Science, King Abdulaziz University, Saudi Arabia
}

*Corresponding Author: Yousef Alghamdi, Department of Chemistry, Faculty of Science, King Abdulaziz University, Saudi Arabia

\begin{abstract}
Thin films based on earth abundant and non-toxic elements comprising Cu2FeSnS4 (CFTS), Cu2FeSnSe4 (CFTSe), Cu2(ZnyFe1-y) SnS4 (CZFTS), Cu2(ZnyFe1-y) Sn (SxSe1-x)4 (CZFTSSe) have been deposited by Aerosol Assisted Chemical Vapour Deposition (AACVD) from mixtures of molecular precursors. These materials are highly important for optoelectronic and solar energy applications. The structure, morphology, composition, optical and electrical properties of the deposited materials were investigated.
\end{abstract}

Keywords: CZTS, CFTS, AACVD, XRD, SEM

\section{INTRODUCTION}

Copper zinc tin sulfide (CZTS) and coper iron tin sulfide materials important absorber materials for solar cells. These materials are made from nontoxic, low cost and earth abundant elements. CZTS has a band gap of $\sim 1.45 \mathrm{eV}$ suitable for the solar spectrum and has a high absorption coefficient $>10^{4}$. Solar cells with CZTS have already demonstrated power conversion efficiency of $\sim 9.2 \%$. ${ }^{1}$ There are few studies reported for materials that can form in both the kesteritic (space group I $48 \mathrm{~m}$ ) and the stannitic (space group I ${ }^{-42 m}$ ) type dependent upon the $[\mathrm{Zn}]:[\mathrm{Fe}]$ ratio. ${ }^{2}$ The addition of iron into CZTS thin films decreases the optical band gap which can improve the Power Conversion Efficiency (PCE) of Thin Film Solar Cells (TFSCs). The solubility of iron in the CZTS derivatives plays a key role in controlling many parameters. ${ }^{3}$

Many techniques including spray pyrolysis, ${ }^{4}$ sputtering, ${ }^{5}$ hybrid sputtering, ${ }^{6}$ sulfurization, ${ }^{7}$ photo chemical deposition, ${ }^{8}$ sol-gel sulferisation, ${ }^{9}$ pulsed laser deposition, ${ }^{10}$ thermal evaporation, ${ }^{11}$ sol-gel spin coating ${ }^{12}$ and spray pyrolysis have been used to deposit CZTS thin films. ${ }^{13}$ A solution based synthesis of CFTS was reported recently using metal salts and sulfur in hot oleylamine to produce the Stannite phase of CFTS nanocrystals with particles of diameter between 15-25 nm. ${ }^{14}$ Jiang et al reported a non-aqueous strategy for the synthesis of hierarchical porous quaternary chalcogenide $\mathrm{Cu}_{2} \mathrm{FeSnS}_{4}$ as hollow chain microspheres by a microwave method using $\mathrm{CuCl}_{2}, \mathrm{FeCl}_{3}, \mathrm{SnCl}_{4}$ and thiourea in benzyl alcohol and octadecylamine. ${ }^{15}$ Recently Guan et al. synthesized flower like CFTS nanoparticles by a microwave method using $\mathrm{Fe}\left(\mathrm{NO}_{3}\right)_{3}, \mathrm{SnCl}_{2}, \mathrm{Cu}\left(\mathrm{NO}_{3}\right)_{2}$ and thiourea in ethylene glycol. ${ }^{16}$ The structure of $\mathrm{Cu}_{2-\mathrm{x}} \mathrm{Fe}_{1-\mathrm{x}} \mathrm{SnS}_{4}$ was investigated by the Reitveld method by Evastigneeva et al. ${ }^{17}$ Zhang et al. have reported the phase controlled synthesis of wurtzitic CFTS nanoparticles with a band gap of $1.50 \mathrm{eV} .^{18}$ The performance of a photovoltaic cells can be further improved by controlling the composition of the material and by the incorporation of extrinsic impurities such as $\mathrm{Fe}$ or Se in place of Zn and S respectively e.g. as in CZTS. ${ }^{19,20}$ Varying the Fe: Zn in CFTS and S:Se ratio in CZTS can tune both the band gap and lattice parameter. ${ }^{18-22}$

Herein we report the thin films deposition of this multinary family of materials by AACVD and the investigation of different parameters affecting the phase, morphology, band gap and electrical resistance of these materials.

\section{EXPERIMENTAL}

\subsection{Synthesis of Precursors}

The compounds $\left.\left[\mathrm{Cu}\left(\mathrm{S}_{2} \mathrm{CNEt}_{2}\right)_{2}\right](\mathbf{1}),\left[\mathrm{Fe}\left(\mathrm{S}_{2} \mathrm{CNEt}_{2}\right)_{3}\right] \mathbf{2}\right),\left[{ }^{\mathrm{n}} \mathrm{Bu}_{2} \mathrm{Sn}\left(\mathrm{S}_{2} \mathrm{CNEt}_{2}\right)_{2}\right](\mathbf{3})$ and $\left[\mathrm{Zn}\left(\mathrm{S}_{2} \mathrm{CNEt}_{2}\right)_{2}\right]$ (4) were synthesised and recrystallized as described in literature. ${ }^{1}$

$\left[\mathrm{Zn}\left(\mathrm{Se}_{2} \mathrm{CNEt}\right)_{2}\right]$ and $\left[\mathrm{Cu}\left(\mathrm{Se}_{2} \mathrm{PPh}_{2}\right)_{2} \mathrm{~N}\right]$ were prepared as reported in literature. ${ }^{23}$ 


\subsection{Deposition of Thin Films}

The thin films were deposited using AACVD. Glass slides $(1 \times 2 \mathrm{~cm})$ were used as substrates for the deposition of thin films. Substrates were thoroughly cleaned and sonicated in acetone for 30 minutes to remove any possible contamination. In a typical deposition experiment, precursor complex (or a suitable combination of precursors) was dissolved in $20 \mathrm{~mL}$ THF taken in a two-necked $100 \mathrm{~mL}$ round-bottom flask. The round-bottom flask was kept in a water bath above the piezoelectric modulator of a PIFCO ultrasonic humidifier (model 1077). The aerosol droplets of the precursor thus generated were transferred into the hot wall zone of the reactor by a carrier gas (Argon). The Argon flow rate was controlled at $180 \mathrm{sccm}$ by a Platon flow gauge. Both the solvent and precursor were evaporated, and the precursor vapor reached the heated substrate surface where thin film was deposited at $300-450{ }^{\circ} \mathrm{C}$.

\subsection{Deposition of CFTS/Se Thin films}

In a typical deposition of CFTS $\left[\mathrm{Cu}\left(\mathrm{S}_{2} \mathrm{CNEt}_{2}\right)_{2}\right](2.80 \mathrm{mmol}),\left[\mathrm{Fe}\left(\mathrm{S}_{2} \mathrm{CNEt}_{2}\right)_{3}\right](1.40 \mathrm{mmol})$, and $\left[\mathrm{Bu}_{2} \mathrm{Sn}\left(\mathrm{S}_{2} \mathrm{CNEt}_{2}\right)_{2}\right](1.40 \mathrm{mmol})$ were mixed in $20 \mathrm{~mL}$ of THF in a two neck flask under argon (200 sccm). Depositions were carried out at 300,350 and $400{ }^{\circ} \mathrm{C}$ on glass substrates for 50 minutes. For CFTSe or CFTSSe different ratios of $\left[\mathrm{Cu}\left(\mathrm{Se}_{2} \mathrm{PPh}_{2}\right)_{2} \mathrm{~N}\right]$ were used.

\subsection{Deposition of CZFTS/Se Thin Films}

Thin films of $\mathrm{Cu}_{2}\left(\mathrm{Zn}_{\mathrm{y}} \mathrm{Fe}_{1-\mathrm{y}}\right) \mathrm{SnS}_{4}$ (CZFTS) were deposited using a mixture of [Cu( $\left.\mathrm{S}_{2} \mathrm{CNEt}_{2}\right)_{2}$ ] $(2.78 \mathrm{mmol}),\left[\mathrm{Fe}\left(\mathrm{S}_{2} \mathrm{CNEt}_{2}\right)_{3}\right](0.7 \mathrm{mmol}),\left[\mathrm{Zn}\left(\mathrm{S}_{2} \mathrm{CNEt}_{2}\right)_{2}\right](0.7 \mathrm{mmol})$ and $\left[{ }^{\mathrm{n}} \mathrm{Bu} \mathrm{Cu}_{2} \mathrm{Sn}\left(\mathrm{S}_{2} \mathrm{CN} \mathrm{Et}\right)_{2}\right]$ $(1.40 \mathrm{mmol})$ in the molar ratio 2: 1: 0.5: 0.5: $1 \mathrm{in} 20 \mathrm{ml}$ THF. The AACVD experiments were carried out as described above at 300 and $350{ }^{\circ} \mathrm{C}$. The Fe-rich compositions of this material were deposited by increasing the ratio of the iron precursor as compared to that of zinc precursor. A mixture of $\left.\left[\mathrm{Cu}\left(\mathrm{S}_{2} \mathrm{CNEt}_{2}\right)_{2}\right](2.78 \mathrm{mmol}),\left[\mathrm{Fe}\left(\mathrm{S}_{2} \mathrm{CNEt}_{2}\right)_{3}\right] 1.0 \mathrm{mmol}\right),\left[\mathrm{Zn}\left(\mathrm{S}_{2} \mathrm{CN}\right.\right.$ $\left.\left.\mathrm{Et}_{2}\right)_{2}\right](0.4 \mathrm{mmol})$ and $\left[{ }^{\mathrm{n}} \mathrm{Bu}_{2} \mathrm{Sn}\left(\mathrm{S}_{2} \mathrm{CNEt}_{2}\right)_{2}\right](1.40 \mathrm{mmol})$ in $2: 1: 0.7: 0.3: 1$ molar ratio in 20 $\mathrm{ml}$ THF was used to deposit films at $350{ }^{\circ} \mathrm{C}$. For CZFTSe and CZFTSSe thin films $\left[\mathrm{Zn}\left(\mathrm{Se}_{2} \mathrm{CNEt}_{2}\right)_{2}\right]$ was used instead of $\left[\mathrm{Zn}\left(\mathrm{S}_{2} \mathrm{CNEt}_{2}\right)_{2}\right]$.

\subsection{Characterization of Thin Films}

A Bruker AXS D8 diffractometer using $\mathrm{Cu} \mathrm{K} \alpha$ radiation with a step size of 0.05 degree over a range of $20-70$ degree with a count rate of $10 \mathrm{~s}$ we used for p-XRD studies. Thin films were mounted flat on non-reflective steel surface and scanned accordingly. Microstructure of the films was studied using Philips XL30 FEG SEM and EDX measurements were carried out using DX4 instrument. Raman spectroscopic measurements taken in Renishaw 1000 micro Raman system includes diode Laser at $514 \mathrm{~nm}$ and $50 \mathrm{~mW}$ power. UV-Vis spectra measurements taken from UV-VIS NIR Perkin Elmer 1050 Spectrometer. Electrical sheet resistance had been measured using Jandel four probe conductivity meter with $1 \mu \mathrm{A}$ current at room temperature.

\section{RESUltS AND DISCUSSION}

\subsection{Thermal Gravimetric Analysis}

Thermal decomposition studies were carried at $10-600{ }^{\circ} \mathrm{C}$; heating rate $10{ }^{\circ} \mathrm{C} \mathrm{min}^{-1}$ under nitrogen. All compounds show rapid single step decomposition between $250-350{ }^{\circ} \mathrm{C}$. The residual mass of $\left[\mathrm{Fe}\left(\mathrm{S}_{2} \mathrm{CNEt}_{2}\right)_{3}\right]$ complex found to be about $18 \%$ which is close to the calculated percentage of $\mathrm{FeS}$ $(17.5 \%)$. The $\left[\mathrm{Bu}_{2} \mathrm{Sn}\left(\mathrm{S}_{2} \mathrm{CNEt}_{2}\right)_{2}\right]$ complex decomposed slightly faster than the other complexes and the residual mass was found to be $\sim 34 \%$ which agrees with the calculated residual mass of $\mathrm{SnS}_{2}$. $\left[\mathrm{Zn}\left(\mathrm{S}_{2} \mathrm{CNEt}_{2}\right)_{2}\right]$ and $\left[\mathrm{Zn}\left(\mathrm{Se}_{2} \mathrm{CNEt}_{2}\right)_{2}\right]$ resulted with $\sim 9-10 \%$ residue which found to be half or less than half of the mass of the expected metal chalcogenides; ZnS (27\%) and ZnSe (20\%) which may be due to sublimation of the complex.

\subsection{CFTS Thin Films}

Deposition of CFTS at all the temperatures produced, thin black, adherent specular films. p- XRD patterns of all these films correspond to the stannite phase of CFTS (ICDD 00-026-0532), cubic crystal system with a space group I-43m. The main peaks appeared at $2 \theta$ values of $28.8,33.0,33.6$, 47.3, 47.6, 57.0, 70.5, 78.4 (Figure 1). The p-XRD pattern of the films deposited at $350{ }^{\circ} \mathrm{C}$ showed a 
match with the Stannite phase (Figure1) whereas those deposited at 300 and $400{ }^{\circ} \mathrm{C}$ were slightly shifted (Figure 1 (b)) due to being tin rich or iron rich stoichiometry.

The morphology of the films deposited at the three different temperatures is shown in Figure 2. The SEM images of those deposited at $300{ }^{\circ} \mathrm{C}$ consist of irregular flakes of $1-2 \mu \mathrm{m}$ which changes to thicker hexagonal plates at $350{ }^{\circ} \mathrm{C}$, with about the same size, further change to irregularly shaped smaller crystallites $\sim 0.5-1 \mu \mathrm{m}$ occurs at $400{ }^{\circ} \mathrm{C}$.

The EDX for films deposited at $350{ }^{\circ} \mathrm{C}$ gave the stoichiometric ratio $\mathrm{Cu}(27.9 \%), \mathrm{Fe}$ (13.89\%), $\mathrm{Sn}$ (15.28\%), S (42.90\%) corresponding to $\mathrm{Cu}_{2.0} \mathrm{Fe}_{1.0} \mathrm{Sn}_{1.2} \mathrm{~S}_{3.5}$, whereas those deposited at $300{ }^{\circ} \mathrm{C}$ were Fe rich and Sn deficient: $\mathrm{Cu}(32.83 \%)$, Fe (14.25\%), Sn (5.57\%), S(50.45\%), $\mathrm{Cu}_{2.2} \mathrm{Fe}_{1.0} \mathrm{Sn}_{0.4} \mathrm{~S}_{3.9}$, deposits at $400{ }^{\circ} \mathrm{C}$ were $\mathrm{Cu}$ rich with composition: $\mathrm{Cu}$ (26.28\%), $\mathrm{Fe}(12.23 \%), \mathrm{Sn}(21.98 \%)$, $\mathrm{S}(39.50 \%), \mathrm{Cu}_{2.1} \mathrm{Fe}_{1.0} \mathrm{Sn}_{1.8} \mathrm{~S}_{3.2}$. The EDX analysis confirmed the slight shift in p-XRD patterns due to the small variation in the composition of the $\mathrm{Cu}_{2} \mathrm{FeSnS}_{4}$ films. Raman spectra showed weaker peaks at $218,285 \mathrm{~cm}^{-1}$ and a strong peak at $321 \mathrm{~cm}^{-1}$ which agree with the reported values for CFTS (Figure 3). ${ }^{24}$ No peaks were observed at $282 \mathrm{~cm}^{-1}(\mathrm{FeS})$, or 190 or $314 \mathrm{~cm}^{-1}(\mathrm{SnS})$ confirming the phase purity of CFTS. ${ }^{25}$ Band gap measurements of the films deposited at $350{ }^{\circ} \mathrm{C}$ and $400{ }^{\circ} \mathrm{C}$ gave values between $1.45-1.50 \mathrm{eV}$ which are close to those reported previously (Figure $5 \mathrm{~d}$ ). The sheet resistance measurement of the films deposited at $350{ }^{\circ} \mathrm{C}$ at room temperature were found to be $2.13 \times 10^{3} \Omega /$ $\mathrm{cm}^{2}$ which is higher than that reported previously for the CZTS and CFTS materials. ${ }^{26-27}$

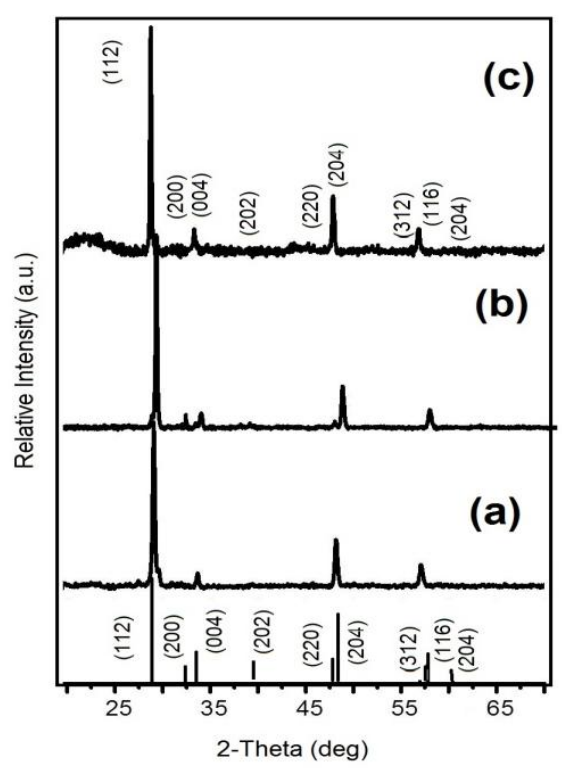

Figure1. (a) p-XRD patterns of films deposited at $300{ }^{\circ} \mathrm{C}, 350{ }^{\circ} \mathrm{C}$ and $400{ }^{\circ} \mathrm{C}$ respectively and (b) $p$-XRD patterns of CFTS films deposited at $350^{\circ} \mathrm{C}$. Peaks are indexed according to ICDD 00-026-0532 (standard stick patterns)

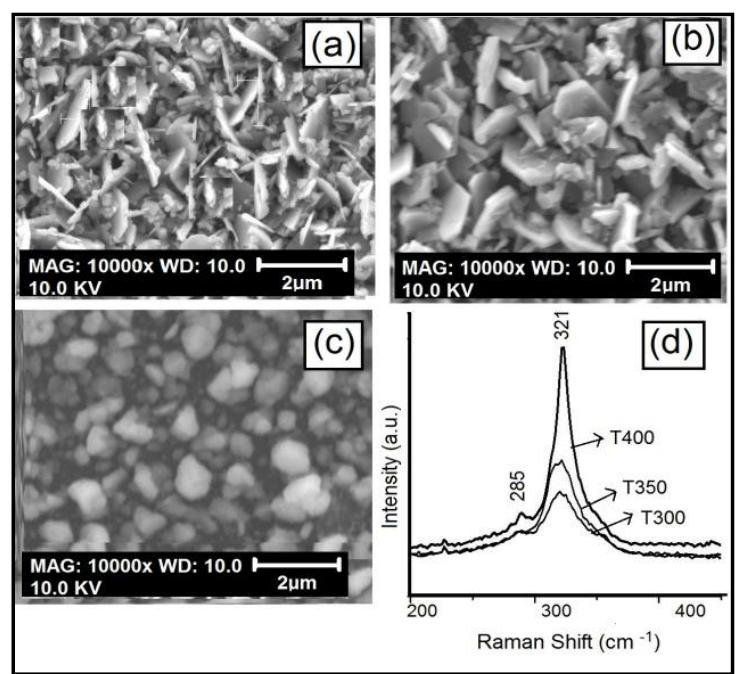

Figure2. (a)-(c) are SEM images of films deposited at 300, 350 and $400{ }^{\circ} \mathrm{C}$ respectively. (d) Raman spectra of films deposited at $300^{\circ} \mathrm{C}, 350^{\circ} \mathrm{C}$ and $400^{\circ} \mathrm{C}$ 


\subsection{CZFTS Thin films}

Thin films of $\mathrm{Cu}_{2}\left(\mathrm{Zn}_{\mathrm{y}} \mathrm{Fe}_{1-\mathrm{y}}\right) \mathrm{SnS}_{4}$ (CZFTS) were deposited using a mixture of $\mathrm{Cu}\left(\mathrm{S}_{2} \mathrm{CNEt}_{2}\right)_{2}(2.78$ $\mathrm{mmol}),\left[\mathrm{Fe}\left(\mathrm{S}_{2} \mathrm{CNEt}_{2}\right)_{3}\right](0.7 \mathrm{mmol}), \mathrm{Zn}\left(\mathrm{S}_{2} \mathrm{CNEt}_{2}\right)_{2}(0.7 \mathrm{mmol})$ and $\left[{ }^{\mathrm{n}} \mathrm{Bu}_{2} \mathrm{Sn}\left(\mathrm{S}_{2} \mathrm{CNEt}_{2}\right)_{2}\right](1.40 \mathrm{mmol})$ in $20 \mathrm{ml}$ THF. At $300{ }^{\circ} \mathrm{C}$ dark green, very thin films were deposited which did not diffract whereas black adherent films were deposited at $350^{\circ} \mathrm{C}$. The p-XRD pattern of this correspond to the Kesteritic phase of $\mathrm{Cu}_{2}(\mathrm{Zn}, \mathrm{Fe}) \mathrm{SnS}_{4}$ (ICDD 01-083-2261) with tetragonal space group I-48m (Figure 3(a)). The SEM images showed the deposition of irregular flakes over the entire area of the substrate (Figure 6(a)). EDX results showed the deposition of the Zn-rich films: $\mathrm{Cu}(28.42 \%), \mathrm{Zn}(8.84 \%), \mathrm{Fe}(3.97 \%)$, $\mathrm{Sn}(15.23 \%), \mathrm{S}(43.54 \%)$ corresponding to $\mathrm{Cu}_{2.2} \mathrm{Fe}_{0.3} \mathrm{Zn}_{0.7} \mathrm{Sn}_{1.2} \mathrm{~S}_{3.4}$.

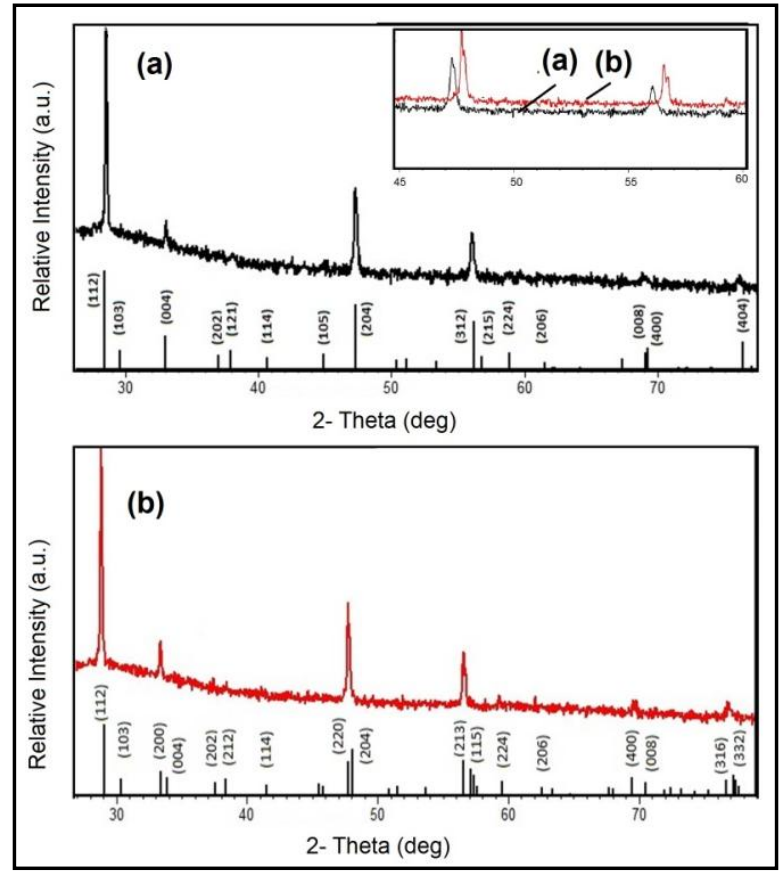

Figure3. (a) and (b) are the Fe rich and Zn rich CZFTS thin films deposited at $350{ }^{\circ} \mathrm{C}$. Inset image shows the enlarged region of $2 \theta: 45$ to $60^{\circ}$

The Fe-rich compositions of this material were deposited by increasing the ratio of the iron precursor as compared to that of zinc precursor in the mixture. A mixture of $\left[\mathrm{Cu}\left(\mathrm{S}_{2} \mathrm{CNEt}_{2}\right)_{2}\right](2.78 \mathrm{mmol})$, $\left[\mathrm{Fe}\left(\mathrm{S}_{2} \mathrm{CNEt}_{2}\right)_{3}\right](1.0 \mathrm{mmol}),\left[\mathrm{Zn}\left(\mathrm{S}_{2} \mathrm{CNEt}_{2}\right)_{2}\right](0.4 \mathrm{mmol})$ and $\left[{ }^{\mathrm{n}} \mathrm{Bu}_{2} \mathrm{Sn}\left(\mathrm{S}_{2} \mathrm{CNEt}_{2}\right)_{2}\right](1.40 \mathrm{mmol})$ in 20 $\mathrm{ml}$ THF was used to deposit films at $3500^{\circ} \mathrm{C}$. The p-XRD pattern of as deposited films correspond to the Stannite phase of $\mathrm{Cu}_{2}(\mathrm{ZnFe}) \mathrm{SnS}_{4}$ (ICDD: 01-083-2262) with I-42m space group as shown in (Fig. 4(b)). SEM images showed a remarkable difference from the other films in morphology (Figure 5 (b)), with uniform flakes. EDX results revealed the composition as $(\mathrm{Cu}(25.92 \%) \mathrm{Zn}(4.52 \%) \mathrm{Fe}$ $(9.5 \%) \mathrm{Sn}(17.52 \%) \mathrm{S}(45.54 \%)$ ) giving an empirical formula of $\mathrm{Cu}_{1.9} \mathrm{Fe}_{0.6} \mathrm{Zn}_{0.4} \mathrm{Sn}_{1.3} \mathrm{~S}_{3.2}$.

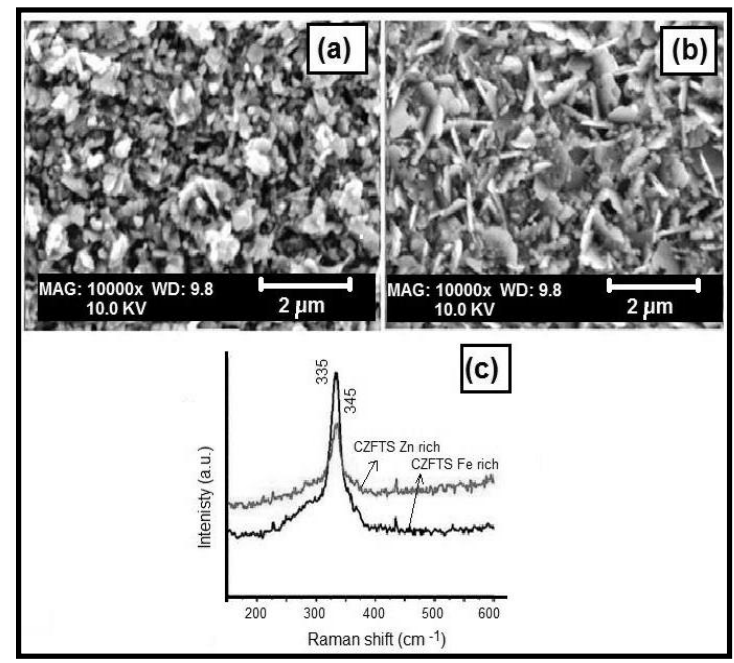

Figure4. (a) and (b) SEM images and (c) Raman spectra of CZFTS Fe rich and Zn rich thin films deposited at $350{ }^{\circ} \mathrm{C}$ 
Raman spectra showed peaks at $\sim 340 \mathrm{~cm}^{-1}$ and $350 \mathrm{~cm}^{-1}$ for the A1 Raman vibration of sulfur atoms in the Kesteric and Stannic phases of the deposited CZTS films respectively. There was a slight variation in positions of peaks for the Zn-rich phase of the CZFTS, as reported previously (Figure 4(c)). ${ }^{28}$ Band gap measurements for Zn-rich composition showed $\sim 1.60 \mathrm{eV}$ whereas those with $\mathrm{Fe}$ rich composition gave a band gap of $\sim 1.51 \mathrm{eV}$, as reported previously (Figure 5). Electrical resistance measured at room temperature were $2.48 \mathrm{~K} \Omega / \mathrm{cm}^{2}$ for Fe-rich thin films and $2.982 .48 \mathrm{~K} \Omega / \mathrm{cm}^{2}$ for Znrich films. Variation in the electrical sheet resistance with different Fe-compositions has been studied. The electrical resistance measured at room temperature were $2.48 \mathrm{~K} \Omega / \mathrm{cm}^{2}$ for Fe-rich thin films and $2.422 .48 \mathrm{~K} \Omega / \mathrm{cm}^{2}$ for Zn-rich films of CZFTS values which lie between the electrical sheet resistance for parent materials CZTS $\left(2.82 .48 \mathrm{~K} \Omega / \mathrm{cm}^{2}\right)$ and CFTS $\left(2.32 .48 \mathrm{~K} \Omega / \mathrm{cm}^{2}\right){ }^{29,30}$

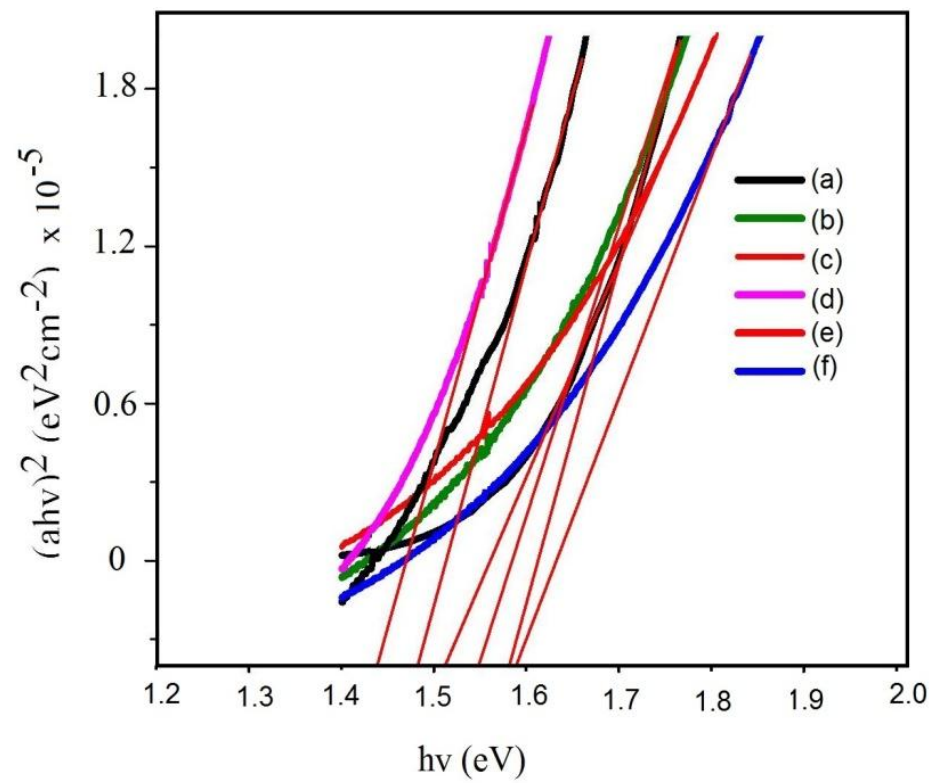

Figure5. (a)-(d) Tauc plots of CZTS and CFTS thin films depoisted at 350 and $400{ }^{\circ} \mathrm{C}$. (e) and (f) are that of $\mathrm{Fe}$-rich and Zn-rich phases of CZFTS thin films deposited at $350^{\circ} \mathrm{C}$

\subsection{CFTSe Thin Films}

The films were deposited at temperatures between 300 and $400{ }^{\circ} \mathrm{C}$ from different mixtures of precursors. The compositions of the films from EDX measurements in the electron microscope are summarized in Table 1. Iron incorporation is consistently close to the stoichiometric ratio calculated from the feed rate. In order to provide a consistent comparison of the films d spacings for each sample were also calculated from the principal peaks with the cubic indices. These are in good agreement for the known phases and the results of Rietveld refinements, all are summarized in Table 1. The CFTSSe thin films deposited using equimolar ratio of selenium and sulfur precursors at 300 and $350{ }^{\circ} \mathrm{C}$ gave thin black, adherent films. The p-XRD patterns of the CFTSSe showed clear shifts from that of CFTS. There seems to be a trace of an impurity in the film deposited at $300{ }^{\circ} \mathrm{C}$ and Rietveld analysis gave no matching with any of the known parent CFTS and CFTSe phases.

Table1. Consolidated p-XRD and EDX analalysis of CFTS, CFTSe and CFTSSe thin films deposited at different temperatures. \$ from peak position and $a^{2}=d^{2}\left(h^{2}+k^{2}+l^{2}\right)$, \& for cubic ICDD 00-530575 gives $a=5.4233 \AA$, for cubic analysis ICDD 00-027-0167 gives $a=5.685 \AA$

\begin{tabular}{|l|l|l|l|l|l|l|l|}
\hline Film & \multirow{2}{*}{$\begin{array}{l}\text { Temp } \\
{ }^{\circ} \mathrm{C}\end{array}$} & Stoichiometry & Rietveldt & Cubic $^{\$}$ & Literature & Literature & (ICDD) [ref] \\
\cline { 4 - 8 } & & $\mathrm{a}$ & $\mathrm{a}$ & $\mathrm{a}$ & $\mathrm{c}$ & \\
\hline CFTS & 300 & $\mathrm{Cu}_{2.1} \mathrm{Fe}_{0.92} \mathrm{Sn}_{1} \mathrm{~S}_{3.3}$ & $5.4328(2)$ & $5.46(2)$ & $5.4495(6)^{\&}$ & $10.726(2)^{\&}$ & {$[20]$} \\
\hline CFTS & 350 & $\mathrm{Cu}_{1.8} \mathrm{Fe}_{0.90} \mathrm{Sn}_{1} \mathrm{~S}_{2.80}$ & $5.4261(6)$ & $5.45(1)$ & $5.4495(6)^{\&}$ & $10.726(2)^{\&}$ & {$[20]$} \\
\hline CFTS & 400 & $\mathrm{Cu}_{1.2} \mathrm{Fe}_{.55} \mathrm{Sn}_{1} \mathrm{~S}_{1.8}$ & $5.414(4)$ & $5.402(1)$ & $5.4495(6)$ & $10.726(2)^{\&}$ & {$[20]$} \\
\hline CFTSSe & 300 & $\mathrm{Cu}_{1.2} \mathrm{Fe}_{0.75} \mathrm{Sn}_{1} \mathrm{~S}_{0.14} \mathrm{Se}_{3.4}$ & - & $5.487(7)$ & - & - & - \\
\hline CFTSSe & 350 & $\mathrm{Cu}_{1.8} \mathrm{Fe}_{0.69} \mathrm{Sn}_{1} \mathrm{~S}_{1.8} \mathrm{Se}_{1.5}$ & - & $5.506(1)$ & - & - & - \\
\hline CFTSSe & 400 & $\mathrm{Cu}_{1.7} \mathrm{Fe}_{0.56} \mathrm{Sn}_{1} \mathrm{~S}_{1.8} \mathrm{Se}_{1.02}$ & - & $5.510(5)$ & - & - & - \\
\hline CFTSe & 350 & $\mathrm{Cu}_{2.74} \mathrm{Fe}_{1.26} \mathrm{Sn}_{1} \mathrm{Se}_{5.9}$ & $5.714(0)$ & $5.663(3)$ & $5.7200^{+}$ & $11.286^{+}$ & $00-052-0098[22]$ \\
\hline CFTSe & 400 & $\mathrm{Cu}_{1.0} \mathrm{Fe}_{.88} \mathrm{Sn}_{1.0} \mathrm{Se}_{2.26}$ & - & $5.64(6)$ & $5.7200^{+}$ & $11.286^{+}$ & $00-052-0098[22]$ \\
\hline
\end{tabular}




\subsection{CZFTSe and CZFTSSe Thin Films}

The deposition of $\mathrm{Cu}(\mathrm{ZnFe}) \mathrm{SnSe}_{4}$ at $300{ }^{\circ} \mathrm{C}$ gave only amorphous material which did not show any diffraction by $\mathrm{p}$-XRD whereas uniform dark brownish films were obtained at 350 ${ }^{\circ} \mathrm{C}$. The p-XRD pattern of the thin films deposited at $350{ }^{\circ} \mathrm{C}$ show clear shifts from Zn-rich $\mathrm{Cu}_{2} \mathrm{ZnFeSnS}_{4}$ (ICDD: 00-83-0225) and Fe-rich $\mathrm{Cu}_{2} \mathrm{ZnFeSnS}_{4}$ (ICDD: 01-015-0228) phase as expected. The p-XRD pattern found to be broader because of the small particle size of

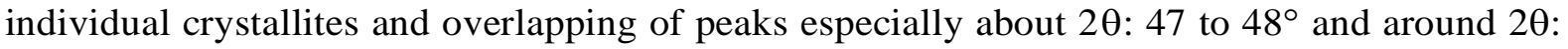
55-56.

A similar deposition with more Fe precursor concentration at $350{ }^{\circ} \mathrm{C}$ gave thin brown films. The pXRD patterns were analysed by comparing with the $\mathrm{Zn}$-rich $\mathrm{Cu}_{2} \mathrm{ZnFeSnS}_{4}$ (ICDD: 00-83-0225) an Fe- rich $\mathrm{Cu}_{2} \mathrm{ZnFeSnS}_{4}$ (ICDD: 01-015-0228) phases, the p-XRD patterns were shifted significantly from the reference patterns. The p-XRD patterns were further analysed using $\mathrm{Cu}_{2} \mathrm{FeSnSe}_{4}$ patterns (JCPDS: 00- 027-0167) but none of the matching peaks were seen.

The deposition of $\mathrm{Cu}_{2}(\mathrm{ZnFe}) \mathrm{Sn}\left(\mathrm{S}_{\mathrm{x}} \mathrm{Se}_{1-\mathrm{x}}\right)_{4}$ using a mixture of precursors as described in the experimental part gave only a negligible amount of deposits at $300{ }^{\circ} \mathrm{C}$ whereas good quality black specular films were deposited at $350{ }^{\circ} \mathrm{C}$. The p-XRD pattern of these films showed a clear shifts from those of the Fe-rich and Zn-rich phases of CZFTS indicating the formation of $\mathrm{Cu}_{2}\left(\mathrm{Zn}_{\mathrm{y}} \mathrm{Fe}_{1-\mathrm{y}}\right) \mathrm{Sn}\left(\mathrm{S}_{\mathrm{x}} \mathrm{Se}_{1-}\right.$ )$_{4}$. The calculated lattice parameter $\mathrm{a}=5.477$ (5) $\AA$. Another deposition with more Fe precursors at $350{ }^{\circ} \mathrm{C}$ produced thin black films. The p-XRD pattern was compared with Fe-rich ((ICDD: 01-0150228) and Zn-rich ((ICDD 04-015-0225) CZFTS patterns. The peaks showed larger shift from both reference patterns. The lattice parameter a calculated from the p- XRD patterns was 5.429 (8) A.

Elemental analysis of the films confirmed that the metal content of all films correlated well with mole fraction of metal in the feed shown in Figure 6. From the graph it shows a linear correlation between the mole fraction of $\mathrm{Se}$ in the precursor and in the deposited thin films.

SEM images with Fe-rich phases of C(ZF)TSe showed irregularly shaped crystallites with EDX analysis showing atomic percentage of $\mathrm{Cu}(26.13 \%), \mathrm{Zn}(4.10 \%), \mathrm{Fe}(11.21 \%), \mathrm{Sn}$ $(13.60 \%)$ and $\mathrm{Se}(44.13 \%)$ which gives a stoichiometric composition of $\mathrm{Cu}_{1.8} \mathrm{Zn}_{0.3} \mathrm{Fe}_{0.7} \mathrm{Sn}_{0.9}$ $\mathrm{Se}_{3.0}$ corresponding to Fe-rich phase. The SEM images of $\mathrm{Cu}_{2}(\mathrm{ZnFe}) \mathrm{Sn}\left(\mathrm{S}_{\mathrm{x}} \mathrm{Se}_{1-\mathrm{x}}\right)_{4}$ thin films deposited at $350{ }^{\circ} \mathrm{C}$ showed irregular plate like crystallites. The EDX analysis gave the atomic percentages as $\mathrm{Cu}(25.63 \%) \mathrm{Zn}(8.74 \%) \mathrm{Fe}(6.46 \%) \mathrm{Sn}(12.46 \%) \mathrm{S}(28.74 \%)$ and $\mathrm{Se}(17.94 \%)$ corresponding to $\mathrm{Cu}_{1.7} \mathrm{Fe}_{0.4} \mathrm{Zn}_{0.6} \mathrm{Sn}_{0.8} \mathrm{~S}_{1.9} \mathrm{Se}_{1.2}$, the $\mathrm{Zn}$-rich and S-rich stoichiometry. The EDX analysis of the $(\mathrm{ZnFe}) \mathrm{Sn}\left(\mathrm{S}_{\mathrm{x}} \mathrm{Se}_{1-\mathrm{x}}\right)_{4}$ films deposited at $350{ }^{\circ} \mathrm{C}$ with higher concentration of $\mathrm{Fe}$ showed $\mathrm{Cu}$ (26.87\%) Zn (5.13\%) Fe (7.92\%) Sn (11.15\%) S (26.24\%) and Se (22.85\%) corresponding to $\mathrm{Cu}_{2.1} \mathrm{Fe}_{0.6} \mathrm{Zn}_{0.4} \mathrm{Sn}_{0.8} \mathrm{~S}_{2.1} \mathrm{Se}_{1.7}$.

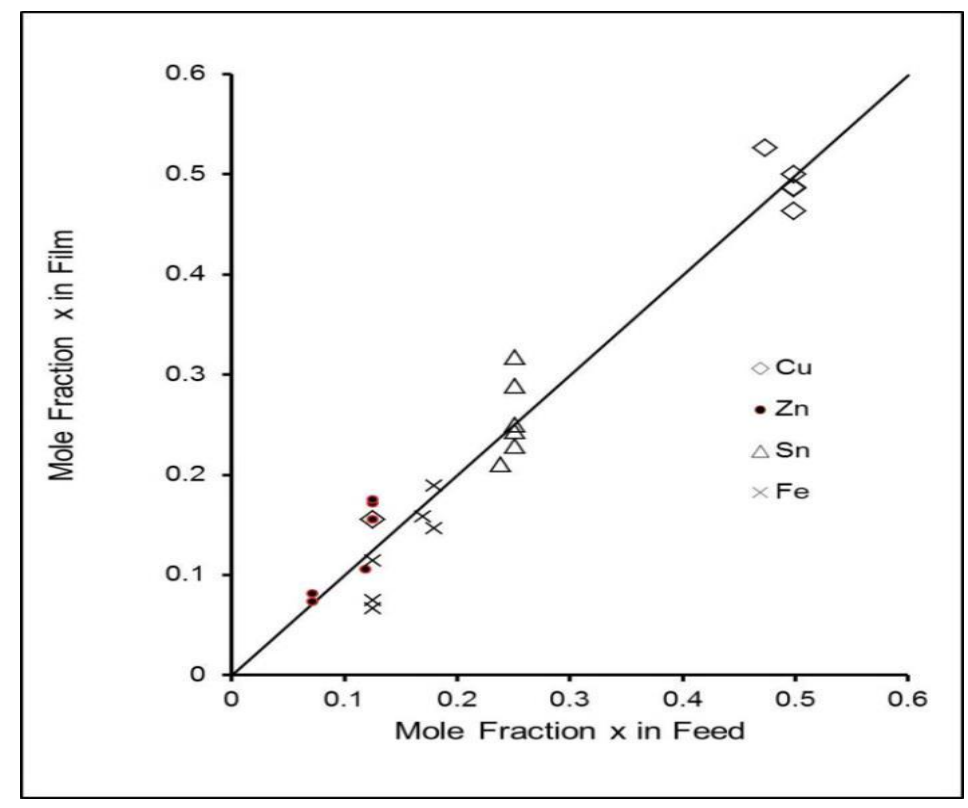

Figure6. Correlation between mole fraction of each metal $(x)$ in the feed and observed amount in the film by EDX 


\section{CONCLUSION}

The materials $\mathrm{Cu}_{2}\left(\mathrm{Zn}_{\mathrm{y}} \mathrm{Fe}_{1-\mathrm{y}}\right) \mathrm{SnS}_{4}(\mathrm{CZFTS}), \mathrm{Cu}_{2}\left(\mathrm{Zn}_{\mathrm{y}} \mathrm{Fe}_{1-\mathrm{y}}\right) \mathrm{SnSe}_{4}(\mathrm{CZFTSe})$ and $\mathrm{Cu}_{2}\left(\mathrm{Zn}_{\mathrm{y}} \mathrm{Fe}_{1-\mathrm{y}}\right)$ $\mathrm{Sn}\left(\mathrm{S}_{\mathrm{x}} \mathrm{Se}_{1-\mathrm{x}}\right)_{4}$ (CZFTSSe) have useful band gaps, large absorption coefficient and transport properties suitable for PV applications. The band gaps of these materials lie between $1.1 \mathrm{eV}$ and $1.7 \mathrm{eV}$ which are ideal for absorber material in thin film solar cells. The ratios of the constituents: $\mathrm{Zn}$ and $\mathrm{Fe}$ and $\mathrm{S}$ and $\mathrm{Se}$ can be controlled by varying the concentrations of corresponding precursors and the deposition temperature to tune the band gap. In contrast to high-vacuum techniques, requiring specialised (and often expensive) equipment, AACVD is performed at ambient pressure and requires inexpensive apparatus. The fabrication of PV devices is underway to measure and compare the photovoltaic efficiency of these materials.

\section{ACKNOWLEDGEMENT}

I thank Department of Chemistry, King Abdulaziz University for supporting this research

\section{REFERENCES}

[1] (a) K. Ramasamy, M. A. Malik, P. O'Brien, Chem. Sci. 2011, 2, 1170; (b) K. Ramasamy, M. A. Malik, P. O’Brien, Chem. Commun., 2012, 48, 5703-5714; (c)D. J. Lewis, P. Kevin, O. Bakr, C. A. Muryn, M. A. Malik, P. O’Brien, Inorg. Chem. Front. 2014, 1, 577.

[2] P. Bonazzi, L. Bindi, G. P. Bernardini, S. Menchetti, Can. Miner, 2003, 41, 639

[3] T. Shibuya, Y. Goto, Y. Kamihara, M. Matoba, K. Yasuoka, L. A. Burton, A. Walsh, Appl. Phys. Lett. 2014, 104, 021912.

[4] N. Nakayama and K. Ito, Appl. Surf. Sci. 1996, 92, 171.

[5] J. Seol, S. Lee, J. Lee, H. Nam, and K. Kim, Sol. Energy Mater. Sol. Cells, 2003, 75, 155.

[6] T. Tanaka, T. Nagatomo, D. Kawasaki, M. Nishio, Q. Guo, A. Wakahara, A. Yoshida, and H. Ogawa, J. Phys.Chem. Solids, 2005, 66, 1978-1981

[7] M. Kurihara, D. Berg, J. Fischer, S. Siebentritt and P. J. Dale, Phys. Status Solidi C, 2009, 6, 1241-1244.

[8] K. Moriya, J. Watabe, K. Tanaka and H. Uchiki, Phys. Status Solidi, 2006, 3, 2848-2852.

[9] K. Tanaka, N. Moritake and H. Uchiki, Sol Energ Mat Sol C, 2007, 91, 1199-1201.

[10] K. Moriya, K. Tanaka and H. Uchiki, Jpn J Appl Phys 1, 2007, 46, 5780-5781.

[11] T. Tanaka, D. Kawasaki, M. Nishio, Q. X. Gu and H. Ogawal, Phys. Status Solidi C, 2006, 3, $2844-2847$.

[12] M. Y. Yeh, C. C. Lee and D. S. Wuu, J Sol-Gel Sci Techn, 2009, 52, 65-68.; Q. Guo, G. M. Ford, W-C. Yang, B. C. Walker, E. A. Stach, H.W. Hillhouse, R. Agrawal, J. Am. Chem. Soc. 2010, 132, 17384-17386.

[13] R. Nitsche, D. F. Sargent, J. Cryst Growth, 1967, 1, 52.

[14] L. Li, X. Liu, J. Huang, M. Cao, S. Chen, Y. Shen, L. Wang, Mater. Chem. Phys. 2012, $133,688$.

[15] L. Ai, J. Jiang, J. Mater. Chem., 2012, 22, 20586.

[16] H. Guan, Y. F. Shi, B. X. Jiao, X. Wang, F. L. Yu, Chalcogenide Lett. 2014, 11, 9.

[17] T. L. Evstigneeva, Y. K. Kabalov, Crystallogr. Rep. 2001, 46, 368.

[18] C. Rincón, M. Quintero, E. Moreno, C. Power, E. Quintero, . A. Henao, M. A. JMacías, G. E. Delgado, R. Tovar, M. Morocoima, Solid State Commun. 2011, 151, 947.

[19] S. Chen, A. Walsh, J.-H. Yang, X. G. Gong, L. Sun, P.-X. Yang, J.-H. Chu, S.-H. Wei, Phys. Rev. B, $2011, \mathbf{8 3}, 125201$.

[20] R. Haight, A. Barkhouse, O. Gunawan, B. Shin, M. Copel, M. Hopstaken, D. B. Mitzi, Appl. Phys. Lett. 2011, 98,253502

[21] G. Marcano, C. Rincón, S. A. López, G. Sánchez Pérez, , J. L. Herrera-Pérez, J. G. Mendoza-Alvarez, P. Rodríguez, Solid State Commun., 2011, 151, 84-86.

[22] D. B. Khadka, J. Kim, J. Phys. Chem. C, 2014, 118, 14227.

[23] M. A. Malik, M. Motevalli, P. O'Brien, J. Mater. Chem. 1992, 2, 949; M. A. Malik, P.O'Brien, Chem., Mater 1991, 3, 999; C Q. Nguyen; A. Adeogun.; M. Afzaal, M. A. Malik, P. O'Brien, Chem. Commun., 2006, 2182

[24] R. Haight, A. Barkhouse, O. Gunawan, B. Shin, M. Copel, M. Hopstaken, D. B. Mitzi, Appl. Phys. Lett. 2011, 98,253502)

[25] X. Zhang, N. Bao, K. Ramasamy, Y.-H. A. Wang, Y.Wang, B. Lin, A. Gupta, Chem. Commun. 2012, 48, 4956; G. Marcano, C. Rincón, S. A. López, G. Sánchez Pérez, , J. L. Herrera-Pérez, J. G. MendozaAlvarez, P. Rodríguez, Solid State Commun., 2011, 151, 84-86., D. B. Khadka, J. Kim, J. Phys. Chem. C, 2014, 118, 14227. 
[26] J-Y. Park, J. H. Noh, T.N. Mandal, S.H. Iam, Y. Jun, S.I. Seok, RSC Adv. 2013, 3, 24918-24921, M. Z. Cao, B. L. Zhang, J. Huang, Y. Sun, L. J. Wang, Y. Shen, Chem. Phys. Lett., 2014, 604, 15-21.,X. Meng, H. Deng, J. He, L. Zhu, L. Sun, P. Yang, J. Chu, Mater. Lett. 2014, 117, 1-3.,

[27] T. Shibuya, Y. Goto, Y. Kamihara, M. Matoba, K. Yasuoka, L.A. Burton, A. Walsh, Appl. Phys. Lett. 2014, 104, 02192. , X. Yu, A. Ren, F. Wang, C. Wang, J. Zhang, W. Wang, L. Wu, W. Li, G.Zeng, L. Feng, International Journal of Photoenergy, 2014 , 6, ID. 846940,E.M. Mkawi, K. Ibrahim, M. K. M. Ali, A. S. Mohamed, Int. J. Electrochem. Sci, 2013, 8, 359 - 368.

[28] S. R. Hall, J. T. Szymanski, J. M. Stewart, Can. Miner. 1978, 16, 131-137, K. G. U. Wijayantha, S. Saremi-Yarahmadia, L. M. Peter, Phys. Chem. Chem. Phys., 2011, 13, 5264-5270.

[29] G. L. Agawane, S.W. Shin, S. A. Vanalakar, A. V. Moholkar, J. H. Kim, Mat. Lett. 2014, 137, 147-149)

[30] S. C. Riha, B. A. Parkinson, A. L. Prieto, J. Am. Chem. Soc., 2011, 133, 15272-15275., C. Jiang, J. S. Lee, D. V. Talapin, J. Am. Chem. Soc., 2012, 134, 5010-5013. X. Zhang, N. Bao, K. Ramasamy, Y. H. A. Wang, Y. Wang, B. Lin, A. Gupta, Chem. Commun., 2012, 48, 4956 ,H. Katagiri, K. Saitoh, T. Washio, H. Shinohara, T. Kurumadani, S. Miyajima, Sol. Energy. Mater Sol. Cells 2001, 65, 141-148)

Citation: Y. Alghamdi, "The AACVD of CFTS Family of Materials", International Journal of Advanced Research in Chemical Science (IJARCS), vol. 4, no. 8, pp. 14-21, 2017. http://dx.doi.org/10.20431/2349-0403. 0408003

Copyright: (C) 2017 Authors. This is an open-access article distributed under the terms of the Creative Commons Attribution License, which permits unrestricted use, distribution, and reproduction in any medium, provided the original author and source are credited. 